\title{
Regulatory Landscape of Regenerative Medicine in Japan
}

\author{
Kentaro Azuma ${ }^{1}$
}

Published online: 18 April 2015

(C) Springer International Publishing AG 2015

\begin{abstract}
Last year, Japan exercised two new acts, the Act on the Safety of Regenerative Medicine (RM Act) and Pharmaceuticals and Medical Devices Act (PMD Act). These acts have significantly changed the conditions for clinical application of regenerative medicine. The RM Act covers clinical research and medical practice using processed cells. It specifies the procedures required for clearance to administer said processed cells to humans. The RM Act also introduces a licensing scheme for cell processing centers outside medical institutions. The PMD Act, on the other hand, introduces a specific regulatory framework for regenerative medicine products. Under the PMD Act, conditional and timelimited marketing approval will be given to a regenerative medicine product after exploratory clinical trials have demonstrated probable benefit and proven safety. Combined with other measures to facilitate $R \& D$, it is expected that these changes will accelerate the clinical application and commercialization of innovative regenerative medicine therapy.
\end{abstract}

Keywords Regenerative medicine - Cell therapy ·

Regulation $\cdot$ iPS cells $\cdot$ Japan

This article is part of the Topical Collection on Stem Cells: Policies from the Bench to the Clinic

Kentaro Azuma

azuma.kentaro@cira.kyoto-u.ac.jp

1 Center for iPS Cell Research and Application, Kyoto University, 53 Kawahara-cho, Shogoin, Sakyo-ku, Kyoto 606-8507, Japan

\section{Introduction}

The discovery of induced pluripotent stem (iPS) cells by Shinya Yamanaka in 2006 [1] and his receipt of the Nobel Prize for Physiology and Medicine in 2012 have attracted intense public attention in Japan to the topic of regenerative medicine. In response, the Japanese National Diet has passed the Regenerative Medicine Promotion Act [2] in May 2013 to clarify national policy regarding regenerative medicine. Adding to this act are two new acts, the Act on the Safety of Regenerative Medicine (RM Act) and the Amended Pharmaceutical Affairs Law (PAL), or Pharmaceuticals and Medical Devices Act (PMD Act), which have significantly changed the conditions for clinical application of regenerative medicine. The RM and PMD acts were enacted on November 2013 and became law on November 2014 [3, 4•, 5•, 6-8].

Since its establishment in 1960, the PAL has regulated drugs, medical devices, quasi-drugs, and cosmetics. It was revised in 2003 to consider products derived from biological ingredients by introducing a biological product category [9], but regenerative medicine products were still categorized either as drugs or medical devices according to their primary mode of action. Two autologous products, JACE (autologous cultured epidermis) and JACC (autologous cultured cartilage), both by Japan Tissue Engineering Co., Ltd., had been originally approved as medical devices [10-12]. Under the PMD Act, however, a new category, regenerative medicine product category, was introduced. Accordingly, JACE and JACC were transferred from the medical device category to the regenerative medicine product category [13].

In Japan, regenerative medicine technologies prepared within medical institutions and used for clinical research or medical treatments have been outside the scope of the PAL or PMD Acts. Clinical research using stem cells, including the first-in-human study using iPS cell-derived retinal pigment 
epithelium cells at RIKEN [14, 15], had been regulated by independent guidelines issued as the Minister's Notification by Ministry of Health, Labour and Welfare (MHLW) since 2006 [16], while other medical treatments and researches were covered by general regulation under the Medical Practitioners' Act and Medical Care Act [17-19]. However, the tragic death of a patient receiving stem cell therapy in Japan intensified the demand for new regulation [20-22]. At the same time, requests to expand centers that could process and manipulate cell products beyond hospitals and clinics to outside companies were also increasing [23]. In response, the RM Act was enacted to regulate regenerative medicine procedures in medical institutions and introduce licensing schemes and standards for cell processing facilities such that these tasks could be subcontracted to outside facilities.

\section{Overview of the Regulatory Framework Covering Regenerative Medicine}

In Japan, regenerative medicine products distributed by companies are regulated under the PMD Act. Clinical trials that collect data to gain approval for regenerative medicine products are also covered by the PMD Act (Article 2(17)). Regenerative medicine products are reviewed by the Pharmaceuticals and Medical Devices Agency (PMDA), an incorporate administrative agency established pursuant to the Pharmaceuticals and Medical Devices Agency Act (PMDA Act) [24] and approved by the Minister of the MHLW. Approved regenerative medicine products are covered by the National Health Insurance (NHI) for medical treatment, in principle.

Clinical research other than clinical trials intended for submission to get approval or daily medical treatments that use unapproved regenerative medicine products are covered by the new RM Act. Thus, cells processed within medical institutions or by outside companies with appropriate licenses can be used for clinical research or medical treatment.

Table 1 summarizes the requirements for regenerative medicine approval according to the RM and PMD acts. Clinical research under the RM act and clinical trials under the PMD act have different data integrity standards. Good clinical practice (GCP) only applies to clinical trials. Clinical research under the RM act has lower data integrity standards; therefore, these data may not be considered as reliable data for approval review under the PMD Act unless they fulfill GCP standards (PMD Act article 23-25(3)). However, exploratory clinical research can be used to design confirmative clinical trials. In the early clinical development phase of regenerative medicine, products in Japan are often first evaluated as clinical research, which is considerably cheaper than clinical trials. If the prediction of success is high, then investigator-initiated or company-sponsored clinical trials may be initiated.
Figure 1 shows the typical development process of regenerative medicine in Japan, according to a report from the special committee of Health Science Council of MHLW that discussed the framework of the new RM Act [25]. Some regenerative medicine therapies begin as clinical research under the RM Act and then move to clinical trial under the PMD Act. Others will directly begin with clinical trials. After clinical trials, marketing approval as a regenerative medicine product and NHI coverage can be awarded. In exceptional cases such as autologous therapy for rare diseases, clinical use under the RM Act might be continued without approval of regenerative medicine product under the PMD Act. Early clinical research is neither covered by NHI nor used in combination with medical treatments that are covered. Satisfactory clinical research may permit NHI coverage if the designation "Advanced Medical Therapy" is assigned by the Minister of the MHLW, even though the regenerative medicine therapy itself is not yet covered by NHI at this stage. Other than the scheme described above, regenerative medicine therapy can be provided by private practices without NHI coverage.

\section{Pharmaceuticals and Medical Devices Act}

\section{Definition of Regenerative Medicine Products under the PMD Act}

The PMD Act has introduced definitions of regenerative medicine products as follows.

(1) Processed human or animal cells intended for either:

(a) the reconstruction, repair, or formation of the structure or function of the human (or animal) body (i.e., tissue-engineered products)

(b) the treatment or prevention of human (or animal) diseases (i.e., cellular therapy products)

(2) Articles intended for the treatment of disease in humans (or animals) and are transgened to express in human (or animal) cells (i.e., gene therapy products) (PMD Act article 2(9)).

Regenerative medicine products under the PMD Act also include those that are used solely on animals and regulated not by the MHLW but by the Ministry of Agriculture, Forestry and Fisheries (PMD Act Article 83).

The cabinet ordinance of the PMD act (Article 1-2, Table 2) further specifies the following three product categories as regenerative medicine products:

(1) Processed human cell products, such as iPS cell-derived products, embryonic stem (ES) cell-derived products or somatic cell products. 
Table 1 Summary of regenerative medicine scheme under regenerative medicine act (RM Act) and pharmaceuticals and medical devices act (PMD act)

\begin{tabular}{|c|c|c|c|c|}
\hline & RM Act & RM Act & PMD Act & PMD Act \\
\hline Scheme & Clinical research & Medical treatment & Clinical trial & Medical treatment \\
\hline Purpose & $\begin{array}{l}\text { Research (not for marketing } \\
\text { approval) }\end{array}$ & Medical treatment & $\begin{array}{l}\text { Application for marketing } \\
\text { approval }\end{array}$ & Medical treatment \\
\hline $\begin{array}{l}\text { Review requirements } \\
\text { before clinical use }\end{array}$ & $\begin{array}{l}\text { Certified IRB approval, } \\
\text { MHLW submission } \\
\text { 90-day review for class I) }\end{array}$ & $\begin{array}{l}\text { Certified IRB approval, } \\
\text { MHLW submission } \\
\text { (90-day review for } \\
\text { class I) }\end{array}$ & $\begin{array}{l}\text { 30-day review by } \\
\text { MHLW/PMDA, IRB } \\
\text { approval }\end{array}$ & $\begin{array}{l}\text { MHLW marketing } \\
\text { approval }\end{array}$ \\
\hline $\begin{array}{l}\text { Responsibility for } \\
\text { safety and quality } \\
\text { of regenerative } \\
\text { medicine }\end{array}$ & $\begin{array}{l}\text { Physician and medical } \\
\text { institutions }\end{array}$ & $\begin{array}{l}\text { Physician and medical } \\
\text { institutions }\end{array}$ & $\begin{array}{l}\text { Physician and medical } \\
\text { institutions (investigator- } \\
\text { initiated trial) or company } \\
\text { (company-sponsored trial) }\end{array}$ & Company \\
\hline $\begin{array}{l}\text { Manufacturing facility } \\
\text { registration }\end{array}$ & $\begin{array}{l}\text { License (outside medical } \\
\text { institution in Japan)/ } \\
\text { accreditation (foreign)/ } \\
\text { notification (within } \\
\text { medical institution) }\end{array}$ & $\begin{array}{l}\text { License (outside medical } \\
\text { institution in Japan)/ } \\
\text { accreditation (foreign)/ } \\
\text { notification (within } \\
\text { medical institution) }\end{array}$ & Not required & $\begin{array}{l}\text { License (domestic)/ } \\
\text { accreditation } \\
\text { (foreign) }\end{array}$ \\
\hline $\begin{array}{l}\text { Manufacturing facility } \\
\text { requirements }\end{array}$ & RM Act Art. 42,44 & RM Act Art. 42,44 & GMP for investigational products & GCTP \\
\hline $\begin{array}{l}\text { Standards for clinical } \\
\text { practice }\end{array}$ & $\begin{array}{l}\text { Provider Rule (RM Act } \\
\quad \text { Art. } 3 \text { to } 25 \text { ) }\end{array}$ & $\begin{array}{l}\text { Provider Rule (RM Act } \\
\quad \text { Art. } 3 \text { to } 25 \text { ) }\end{array}$ & GCP & $\begin{array}{l}\text { Post-market safety } \\
\text { requirements (PMD } \\
\text { Act Art. } 68-2 \text { to } 68-15 \text { ) }\end{array}$ \\
\hline $\begin{array}{l}\text { National health } \\
\text { insurance }\end{array}$ & Not covered (in principle) & Not covered (in principle) & Partially covered & Fully covered (in principle) \\
\hline
\end{tabular}

IRB Institutional review board (certified regenerative medicine committee under the RM Act), GCP good clinical practice, GMP good manufacturing practice, GCTP good gene, cellular, and tissue-based products manufacturing practice

(2) Processed animal cell products

(3) Gene therapy products

Under the PMD Act, platelets derived from iPS cells [26] are classified as processed human cell products and regulated not as blood derivatives under the category
Drug, but as Regenerative Medicine Products. Regenerative medicine products include gene therapy products, which are products that introduce genes to cells that are already in the human body (in vivo) or have been extracted from but then transplanted back to the human body (ex vivo).

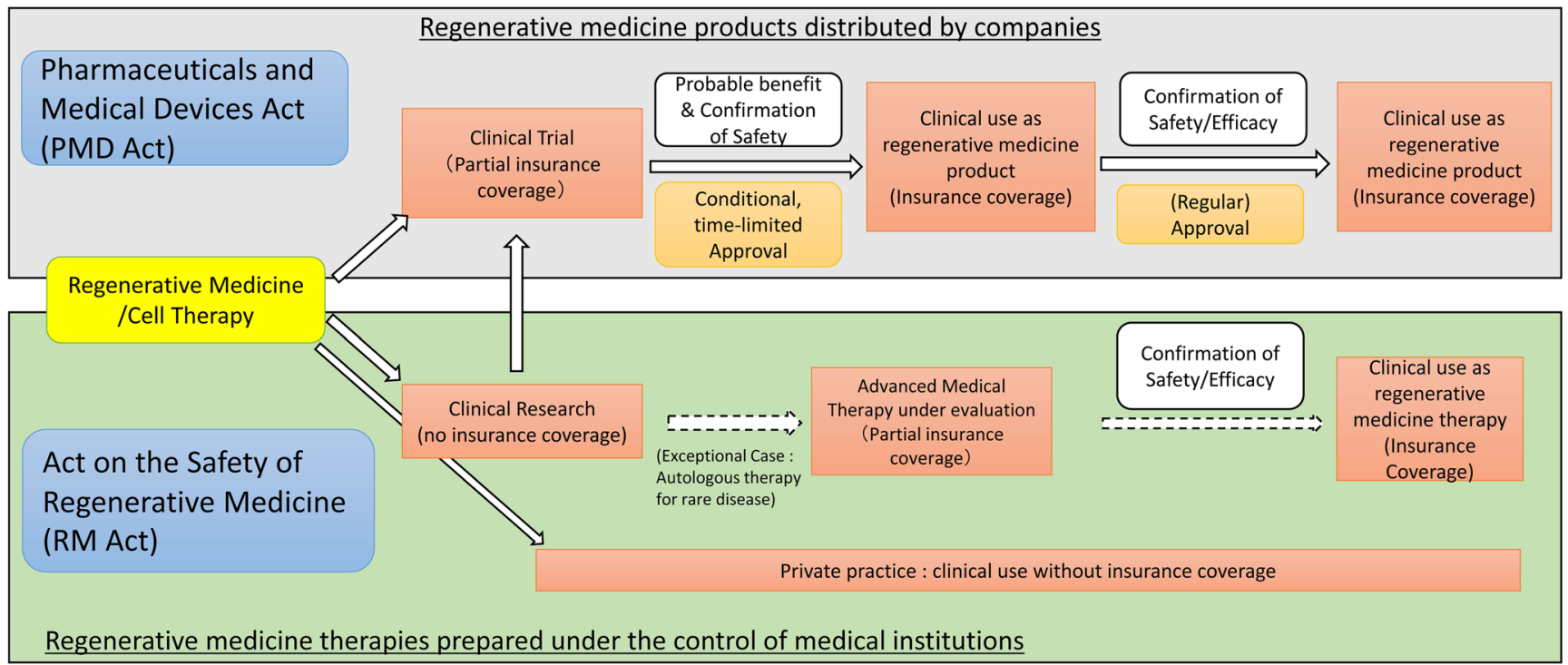

Fig. 1 Regulatory process of regenerative medicine. (Adapted from a report of the Special Committee to promote and secure safe regenerative medicines, Health Science Council, MHLW, April 18, 2013; http://www.mhlw.go.jp/stf/shingi/2r9852000002zggt.html) 
Table 2 Important regulations and guidance documents related to regenerative medicine products under the PMD act

Name of regulations or guidance documents

1. Regulations

Pharmaceuticals and Medical Devices Act

Revised cabinet ordinance for the enforcement of the PMD Act

Revised cabinet ordinance for user fees related to the PMD Act

Revised ministerial ordinance for the enforcement of the PMD Act

Revised MHLW ministerial ordinance for user fees related to the PMD Act

GLP (good laboratory practice)

GCP (good clinical practice)

GPSP (good post-market study practice)

GCTP (good gene, cellular, and tissue-based products manufacturing practice)

GQP (good quality practice)

Regulations for buildings and facilities

GVP (good vigilance practice)

Standards for biological ingredients

2. Major administrative guidance documents

Guidance on designation of biological products and regenerative medicine products

Guidance on clinical trial notification

Guidance on adverse event reporting during clinical trial

Guidance on application for marketing authorization

Guidance on drug master file

Guidance on data integrity inspection

Guidance on GCTP/GQP/regulations for buildings and facilities

Guidance on package insert/instruction for use

Guidance on post-market adverse event reporting

Guidance on periodic infectious disease surveillance reports

3. Other guidance related to product quality, safety, and efficacy

Guidance on standards for biological ingredients

General principles for the handling and use of cells/tissue-based products

Guideline on ensuring the quality and safety of products derived from processed:

Autologous human cells/tissues

Allogeneic human cells/tissues
Official number of act, cabinet ordinance (CO), MHLW Ministerial ordinance (MO), MHLW Minister's notification (MN), and related guidance

1960 Act No. 145 revised by 2013 Act No. 84 (November 27, 2013)

1961 CO No. 11 revised by 2014 CO No. 269 (July 31, 2014)

2005 CO No. 91 Revised by 2014 CO No. 269 (July 31, 2014)

1961 MO No. 1 revised by 2014 MO No. 87 (July 31, 2014) and PFSB Director Notice 0806 No. 3 (August 6, 2014)

2000 MO No. 63 revised by 2014 MO No. 87 (July 31, 2014) and PFSB Director Notice 0812 No. 35 (August 12, 2014)

2014 MO No. 88 (July 31, 2014), PFSB Director Notice 0812 No. 20 (August 12, 2014), ELD Director Notice 1121 No. 9, and MRED Director Notice 1121 No. 13 (November 21, 2014)

2014 MO No. 89 (July 31, 2014), PFSB Director Notice 0812 No. 16 (August 12, 2014), and MRED Director Notice 1121 No. 3 (November 21, 2014)

2014 MO No. 90 (July 31, 2014), PFSB Director Notice 0812 No. 23 (August 12, 2014), and MRED Director Notice 1121 No. 7 (November 21, 2014)

2014 MO No. 93 (August 6, 2014), PFSB Director Notice 0812 No. 11 (August 12, 2014), and Compliance Division Director Notice 1009 No. 4 (October 9, 2014)

2004 MO No. 136 revised by 2014 MO No. 87 (July 31, 2014) and PFSB Director Notice 0812 No. 11 (August 12, 2014)

1961 MO No. 2 revised by 2014 MO No. 87 (July 31, 2014) and PFSB Director Notice 0812 No. 11 (August 12, 2014)

2004 MO No. 135 revised by 2014 MO No. 87 (July 31, 2014) and PFSB Director Notice 0812 No. 1 (August 12, 2014)

2003 MN No. 210 revised by 2014 MN No. 375 (September 26, 2014) and PFSB Director Notice 1002 No. 27 (October 2, 2014)

ELD Director Notice 1105 No. 1 and MRED Director Notice 1105 No. 2 (November 5, 2014)

PFSB Director Notice 0812 No. 26 and MRED Director Notice 0812 No. 1 (August 12, 2014)

PFSB Director Notice 1002 No. 23 and MRED Director Notice 1002 No. 1 (October 2, 2014)

PFSB Director Notice 0812 No. 30 and MRED Director Notice 0812 No. 5 (August 12, 2014)

ELD Director Notice 1117 No. 3 and MRED Director Notice 1117 No. 1 (November 17, 2014)

MRED Director Notice 1121 No. 11 (November 21, 2014)

Compliance Division Director Notice 1009 No. 1 (October 9, 2014)

PFSB Director Notice 1002 No. 12 and Safety Division Director Notice 1002 Nos. 9 and 13 (October 2, 2014)

Safety Division Director Notice 1002 No. 17 (October 2, 2014)

PFSB Director Notice 0812 No. 7 (August 12, 2014) and Safety Division Director Notice 1113 No. 4 (November 13, 2014)

ELD Director Notice 1002 No. 1 and MRED Director Notice 1002 No. 5 (October 2, 2014)

Pharmaceutical and Medical Safety Bureau Director Notice No. 1314 Appendix 1(December 26, 2000)

PFSB Director Notice 0208 No. 3 (February 8, 2008)

PFSB Director Notice 0912 No. 6 (September 12, 2008) 
Table 2 (continued)

Name of regulations or guidance documents

Human embryonic stem cells

Autologous human somatic stem cells

Allogeneic human somatic stem cells

Autologous human induced pluripotent stem(-like) cells

Allogeneic human induced pluripotent stem(-like) cells

Points to considers for the evaluation of specific products:

Cell sheet for heart failure

Corneal epithelial cell sheet

Corneal endothelial cell sheet

Articular cartilage repair

Cell sheet for periodontal tissue regeneration

Autologous iPS cell-derived retinal pigment epithelial cells

Allogeneic iPS cell-derived retinal pigment epithelial cells
Official number of act, cabinet ordinance (CO), MHLW Ministerial ordinance (MO), MHLW Minister's notification (MN), and related guidance

PFSB Director Notice 0907 No. 1 (September 7, 2012)

PFSB Director Notice 0907 No. 2 (September 7, 2012)

PFSB Director Notice 0907 No. 3 (September 7, 2012)

PFSB Director Notice 0907 No. 4 (September 7, 2012)

PFSB Director Notice 0907 No. 5 (September 7, 2012)

OMDE Director Notice 0118 No. 1 (January 18, 2010)

OMDE Director Notice 0118 No. 1 (January 18, 2010)

OMDE Director Notice 0528 No. 1 (May 28, 2010)

OMDE Director Notice 1215 No. 1 (December 15, 2010)

OMDE Director Notice 1207 No. 1 (December 7, 2011)

OMDE Director Notice 0529 No. 1 (May 29, 2013)

MRED Director Notice 0912 No. 2 (September 12, 2014)

PFSB Pharmaceutical and Food Safety Bureau, ELD Evaluation and Licensing Division, MRED Medical Device and Regenerative Medicine Product Evaluation Division, $O M D E$ Office of Medical Device Evaluation

\section{Pharmaceutical Affairs Consultation and Clinical Trial Notification}

In the PMD Act, sponsors must submit a clinical trial plan, or "Clinical Trial Notification." The PMDA requires 30 days to review this submission before a clinical trial may be approved (PMD Act Article 80-2). Since regenerative medicine products are very complex, a "Pharmaceutical Affairs Consultation on R\&D strategy" is required with the PMDA before submitting a Clinical Trial Notification. Here, the PMDA will review the quality and safety of the investigational regenerative medicine product based on the product specification, appropriateness of the pre-clinical tests, information of the animal- or human-derived materials, etc. Although Clinical Trial Notifications do not require review fees, the Pharmaceutical Affairs Consultation does. Under specific conditions, start-up companies and academia may be eligible for a $90 \%$ discount. It should be noted that there are several additional categories of PMDA consultations, so it is possible for sponsors to discuss other questions, such as the design of clinical trials (additional fees apply). GCP for regenerative medicine products, the standard for which are equivalent to the ICH-E6 guideline (ICH-GCP) [27], applies to clinical trials.

\section{Marketing Approval Review}

Before introducing regenerative medicine products into the market of Japan, it is necessary to get marketing approval from the Minister of the MHLW. Most of the review operations (scientific evaluation) are commissioned from the MHLW to PMDA based on the PMD Act, but the MHLW has the final approval decision. The MHLW retains the authority to make policy including regulation and guidance. Descriptions of the procedures for consultation (pre-application meeting), application, and review are provided by several guidance documents issued by the MHLW and PMDA (see Table 2). After approval, review reports and summaries of the application data, excluding trade secrets, are published on the PMDA's website.

General requirements for approval, such as whether benefits outweigh the risks of the product, are specified in the PMD Act (Article 23-25). Further points to consider relate to quality, efficacy, and safety are provided by the several guidance documents issued by the MHLW (Table 2). It should be noted that Standards for Biological Ingredients, which covers the regulation of source materials derived from human or animals, is one of the most important documents before and after product approval, since products that violate this standards are not allowed to be sold in Japan (PMD Act Article 65-6).

\section{Conditional and Time-Limited Approval}

The PMD Act introduced conditional and time-limited approval specifically for regenerative medicine products (PMD Act Article 23-26). Considering the characteristics of these products, it is normally difficult to evaluate efficacy due to the considerable variation caused by the different donors or cells. Therefore, conditional and time-limited approval requires confirmation of safety and demonstration of probable benefit. Demonstration of probable benefit can be done by data that predicts efficacy through surrogate end points in a relatively small exploratory study. After conditional and timelimited approval, it is possible to market products, but it is necessary to conduct patient follow-up to confirm safety and 
efficacy further. Conditions can be implemented that restrict users, such as making the product only available from medical institutions that have relevant facilities or physicians who have relevant expertise and training. Application forms for conditional and time-limited approval are the same as regular approval. Thus, during the review, the PMDA and MHLW will decide whether which type of approval is appropriate. It is required to apply for regular approval under article 23-25 of the PMD Act within the specified period (normally maximum 7 years) following conditional and time-limited approval, as conditional and time-limited approval will expire thereafter (PMD Act Article 23-26).

\section{Designation of Orphan Products and Priority Review}

Common to the scheme for drugs and medical devices [28], regenerative medicine products used to treat intractable diseases can be subject to orphan product designation and priority review. Designation criteria for orphan regenerative medicine products are as follows: (1) prevalence of the disease covered by the indication of the product concerned is less than 50,000 patients in Japan and (2) the product will be extremely beneficial from a medical standpoint if approved (PMD Act Article 77-2 and MHLW Ministerial Ordinance for the Enforcement of the PMD Act Article 251). Products designated as orphan regenerative medicine products are entitled to priority measures, such as financial aid, tax relief, and priority consultation and priority review (PMD Act Articles 77-3 and 77-4). Products designated as orphan regenerative medicine products as well as other products highly needed from a medical standpoint can receive priority review status (PMD Act Article 23-25(7)).

\section{Licensing for Marketing Authorization Holder and Manufacturing Site}

In the PMD Act, the representative who will market and hold responsibility for the regenerative medicine product must receive a license from local (prefecture) governments that deems him a Marketing Authorization Holder (PMD Act article 2320, 81). The holder must follow quality assurance standards (good quality practice, GQP), post-marketing safety standards (good vigilance practice, GVP), as well as human resource requirements specified in the ministerial ordinance (PMD Act Article 23-21). In addition, the holder must have a responsible office in Japan.

Each manufacturing site of regenerative medicine products must have a license (for domestic sites) or accreditation (for foreign sites) from the MHLW (PMD Act Article 23-22, 2324). Manufacturers must comply with building and facility standards, manufacturing and quality standards (good gene, cellular, and tissue-based products manufacturing practice, GCTP) and human resource requirements (PMD Act Article
23-22, 23-24, 23-25). PMDA conducts audits for both domestic and foreign manufacturing sites (PMD Act Article 23-23).

\section{Post-Market Safety and Distribution Control of Regenerative Medicine Products}

There are several regulatory requirements to ensure postmarket safety and quality of regenerative medicine products. Marketing authorization holders, distributors, and medical institutions and medical practitioners are subject to these requirements. All stake holders in the supply chain must keep records to ensure traceability so that it is possible to conduct surveys if infection occurs (PMD Act Article 68-7). Both Marketing authorization holders and medical practitioners must report serious adverse events, infectious events, or any other issues related to the safety and efficacy of the product(s) to PMDA within a specified timeframe (PMD Act Article 68-10, 6813). In addition, Marketing authorization holders must periodically provide infectious research reports related to the product(s) and source material(s) to the PMDA; these reports are called Periodic Infectious Disease Surveillance Reports (PMD Act Article 68-14, 68-15). Distributors must have a license from local governments; compliance with building and facility standards, human resource requirements, and good distribution practice are required for distributors (PMD Act Article 40-5, 40-6, 40-7). Medical practitioners are expected to inform safety, efficacy, and other information related to the appropriate use of regenerative medicine products to patients before provision to receive informed consent (PMD Act Article 68-4).

\section{Relief Systems for Sufferers of Adverse Events or Infections from the Use of Regenerative Medicine Products}

PMDA operates two relief fund systems related to regenerative medicine products: the Adverse Reaction Relief Fund System and Relief Fund System for Infections (PMDA Act Article 15). The Adverse Reaction Relief Fund System is designed to help sufferers of serious adverse events from the appropriate use of pharmaceuticals or regenerative medicine products. The Relief Fund System for Infections is designed to help sufferers of infectious disease from the use of human- or animal-derived products, including regenerative medicine products. These funds are operated by government subsidy and contributions from marketing authorization holders based on annual sales (PMDA Act Articles 19 and 21).

\section{Other Regulations Related to Some Regenerative Medicine Products}

Gene therapy products and recombinant viruses used for the derivation of iPS or other cells are subject to the Cartagena 
Domestic Act [29]. This act was legislated in 2003 to ratify the Cartagena Protocol on Biosafety to the Convention on Biological Diversity.

The collection of human blood, including that used to derive iPS cells, is subject to the Act on Securing a Stable Supply of Safe Blood Products [30]. Under article 16 of this act, remuneration for blood donations is prohibited.

\section{The Act on the Safety of Regenerative Medicines (RM Act)}

\section{Regenerative Medicine Under the RM Act}

The structure of the RM Act and related regulations are summarized in Table 3. Unlike the PMD Act, which has a number of separate MHLW ministerial ordinances (Table 2), the RM Act has many of its requirements stated in its Cabinet Ordinance and MHLW Ministerial Ordinance for Enforcement [31, 32].

The RM Act covers regenerative medicines defined as medical therapies using the following technologies (RM Act article 2): processed human or animal cells (1) that are intended to be used for (a) the reconstruction, repair, or formation of the structure or function of the human body or (b) the treatment or prevention of human diseases, and (2) that are designated in the Cabinet Ordinance. Under Article 1 of the Cabinet Ordinance for the Enforcement of the RM Act, blood transfusion, hematopoietic stem cell transplantation, and reproductive medicine are excluded from the scope of regenerative medicine in principle. Organ transplantation and tissue plantation, if minimally manipulated, are also considered outside of the scope of the RM Act [33].

\section{Registration and Licensing of Cell Processing Facilities}

Each cell processing facility must receive a license from the MHLW to operate. Domestic cell processing facilities outside medical institutions need to apply for license to the MHLW Regional Bureau (RM Act Article 35), and PMDA may audit the facility (RM Act Article 38). Applicants are required to pay a registration tax to the Japanese government and audit fees to the PMDA [34]. Licenses are effective for 5 years (Cabinet Ordinance for the Enforcement of the RM Act, Article 4) and renewal is necessary with applicable renewal fees. Instead of licenses, foreign cell processing facilities require accreditation from MHLW in order to supply processed cells for regenerative medicine to medical intuitions in Japan (RM Act Article 39). Cell processing facilities inside medical institutions need to notify the MHLW Regional Bureau (RM Act Article 40). Neither a registration tax nor PMDA audit fee are necessary for notification.

\section{Standards for Cell Processing Facilities}

Building and facility standards (RM Act Article 42) and manufacturing and quality control standards (RM Act Article 44) are applied to cell processing facilities both inside and outside medical institutions under the RM Act. These standards share the same principles as GCTP or good manufacturing practice (GMP) based on the PMD Act, but with slightly less rigorous requirements since early phase clinical research is mainly conducted in an academic setting.

\section{Certified Regenerative Medicine Committee}

Under the RM Act, institutional review boards (IRBs) need certification from the MHLW to be recognized as Certified

Table 3 Structure of the RM Act and related regulations

\begin{tabular}{|c|c|c|c|}
\hline Regulations & $\begin{array}{l}\text { RM act } \\
\text { Act No. } 85 \\
\text { (November 27, 2013) }\end{array}$ & $\begin{array}{l}\text { Cabinet ordinance for the } \\
\text { enforcement of the RM act } \\
\text { Cabinet ordinance No. } 278 \\
\text { (August } 8,2014 \text { ) }\end{array}$ & $\begin{array}{l}\text { MHLW Ministerial Ordinance for } \\
\text { the enforcement of the RM act } \\
\text { MHLW ministerial ordinance } \\
\text { No. } 110 \text { (September } 26,2014 \text { ) }\end{array}$ \\
\hline Purpose of the act & Article 1 & & \\
\hline Definition & Article 2 & Article 1 & Article $1-3$ \\
\hline Rule related to provider & Article 3-25 & Article 2 & Article 4-41 \\
\hline $\begin{array}{l}\text { Rule related to certified regenerative } \\
\text { medicine committee (IRB) }\end{array}$ & Article $26-34$ & & Article $42-71$ \\
\hline Rule related to cell processing facility & Article $35-54$ & Article 3-6 & Article $72-112$ \\
\hline Standard for buildings and facilities & Article 42 & & Article 89 \\
\hline Manufacturing and quality control & Article 44 & & Article $91-110$ \\
\hline Supervision & & & Article $113-117$ \\
\hline Miscellaneous (incl. user fee) & Article $55-58$ & Article 7-8 & Article $118-124$ \\
\hline Punishment & Article 59-64 & & \\
\hline
\end{tabular}


Regenerative Medicine Committees. Class I (high risk) and class II (intermediate risk) regenerative medicines are expected to receive higher level of review and thus membership and requirements of the Certified Regenerative Medicine Committee are also high. Those that meet these standards are called Specially Certified Regenerative Medicine Committees (RM Act Article 7). Certified Regenerative Medicine Committees can be set inside or outside medical institutions and function like a central IRB, which receives applications from both inside or outside institutions. The MHLW subsidizes Clinical Research Core Hospitals to facilitate the establishment of Specially Certified Regenerative Medicine Committees in order to introduce the new RM Act efficiently. Certifications of Regenerative Medicine Committees are effective for 3 years and renewal is necessary (RM Act Article 28).

\section{Review Scheme for the Provision of Regenerative Medicine}

Regenerative medicines under the RM Act are divided into following three categories according to their risk to humans. Every plan for the provision of regenerative medicine must be reviewed by a Certified Regenerative Medicine Committee (and the MHLW for class I) prior to the provision in accordance with the specific review scheme set for each category.

(1) Class I (high risk)

Regenerative medicines using processed cells derived from iPS or ES cells, transgened cells or allogeneic cells. Reviews by both Specially Certified Regenerative Medicine Committee and the Health Science Council of the MHLW are necessary. The regular review period of the MHLW is 90 days, after which regenerative medicine therapy can begin unless the review period is extended (RM Act Article 8, 9).

(2) Class II (intermediate risk)

Most stem cell therapies (other than class I) using cultured cells and cell therapies for non-homologues use fall into this category. Review by a Specially Certified Regenerative Medicine Committee and submission of the plan to the MHLW are required. Following review approval and submission, regenerative medicine therapy can begin.

(3) Class III (low risk)

This class includes cell therapies not classified as class I or II and used for the treatment of disease without the use of stem cell or cells for nonhomologous use. Reviews by a Certified Regenerative Medicine Committee and submission of plan to the MHLW are necessary.

\section{Standards for Provision of Regenerative Medicine}

Articles 3 to 25 of the RM Act specify requirements for medical institutions and physicians who provide regenerative medicine. These requirements include informed consent from donors who provide the source cells and from recipients prior to the provision of those cells (RM Act Article 14), protection of personal information related to the donors and recipients (RM Act Article 15), record retention (RM Act Article 16), expedited reports of serious adverse events or periodical reports of the results of the provision to the Certified Regenerative Medicine Committee and the MHLW (RM Act Articles 17, 18, 20, and 21) and confirmation of the quality of the processed cells provided by the cell processing facilities (MHLW Ministerial Ordinance of the Enforcement of the RM Act Article 10). In the case of clinical research, appropriate provision of indemnification is also required (RM Act Article 3(2)(iv)).

\section{Other Important Legislation Related to Regenerative Medicine}

\section{Regenerative Medicine Promotion Act}

The Regenerative Medicine Promotion Act was enacted on May 2013 [2]. This act specifies basic policy related to research and development (R\&D) and provision and dissemination of regenerative medicines so that Japanese citizens receive safer regenerative medicine timely. Both the RM Act and PMD Act were legislated in accordance with the Regenerative Medicine Promotion Act. In pursuant of Article 6 of this act, "Basic Policy to Promote the R\&D, Provision and Dissemination of Regenerative Medicine Timely and Safely" was formulated as a Cabinet Decision on November 25, 2014 [35].

\section{Establishment of Japan Agency for Medical Research and Development (AMED)}

In order to promote medical research and development, including regenerative medicine, the Act on the Incorporated Administrative Agency for Medical Research and Development [36] and the Act to Promote Healthcare and Medical Strategy [37] were legislated on May 2014. Under the former act, the Agency for Medical Research and Development (AMED) will be established as a new National Research and Development Agency in April 2015 [36, 38]. Function and allocation of national medical R\&D funding, currently operated by the Ministry of Education, Culture, Sports, Science and Technology (MEXT); MHLW; and Ministry of Economy, Trade and Industry (METI) directly or through related incorporated administrative agencies such as Japan Science and Technology Agency (JST), National Institute of Biomedical Innovation (NIBIO), and New Energy and Industrial Technology Development 
Organization (NEDO) will be consolidated to the AMED from April 2015. Under the latter act, "Headquarter of Promotion of Healthcare and Medical Strategy," which formulates policy on the allocation of medical R\&D funding and basic policy on the operation of the AMED, was formally established under the Cabinet Secretariat June 2014. This headquarter formulated "Healthcare and Medical Strategy" [39] and "Plan for the Promotion of Medical Research and Development" [40] in July 2014. These two documents indicate basic policy and priorities for medical R\&D.

\section{Patent Term Extensions Under the Patent Act}

Common to the scheme for drugs and medical devices, considering the inevitable time of clinical trials and regulatory review to secure product safety, the extension of the patent term up to 5 years for regenerative medicine products is allowed under the Patent Act (Patent Act Article 67 (2), Cabinet Ordinance for the Enforcement of the Patent Act article 3(ii)(d)) [41-43]. Extensions are applicable to conditional and time-limited approval $[42,44]$.

\section{National Health Insurance Reimbursement Scheme}

Under NHI, the financial expenses relating to a medical treatment is payable by insurers and the insured person to medical institutions, as prescribed by the MHLW Minister's Notification (Health Insurance Act Article 76(2)) [45]. The reimbursement price of two approved regenerative medicine products are listed in the insurance-covered medical material price list: (1) JACE (autologous cultured epidermis), JPY 314,000 (per one sheet $(8 \times 10 \mathrm{~cm})$ ), and (2) JACC (autologous cultured cartilage), JPY 2,130,000 [46].

With the introduction of the regenerative medicine product category to the PMD Act, Central Social Insurance Medical Council of MHLW agreed to new rules for these products on November 5, 2014 [47].

(1) Listing to the NHI Drug Price List or Medical Material Price List

Newly approved regenerative medicine products, including conditional and time-limited approved regenerative medicine products, can be listed either in the NHI Drug Price List [48] or NHI Medical Material Price List on a case by case basis that considers the characteristics of each product and reviews under the PMD Act. A separate regenerative medicine price list will not be created for the time being, but will be considered as more regenerative medicine products are added to the list.

(2) Allowance of medical treatment combined with treatment outside insurance coverage

Under the NHI reimbursement scheme, it is generally not allowed to combine medical treatment covered by insurance with a treatment that is not except for specifically designated treatments, such as "Evaluation Treatment" or "Selective Treatment" (Health Insurance Act Article 86). Clinical trials of regenerative medicine products under the PMD Act are designated as Evaluation Treatment, therefore a combination of insurancecovered and -uncovered treatments using Investigational Processed Cells (unapproved regenerative medicine products) is permitted [49]. For company-sponsored clinical trials, the expense of the medical treatment other than examination, imaging and Investigational Processed Cells can be subject to NHI reimbursement [50]. For investigator-initiated clinical trials, the expense of the medical treatment other than Investigational Processed Cells can be subject to NHI reimbursement [50]. Regenerative medicine therapies under clinical research or medical treatment under the RM Act are generally outside NHI coverage and not permitted to be combined with other medical treatments covered by NHI. However, it is possible to designate these regenerative medicine therapies as Advanced Medical Therapy under the Evaluation Treatment category after a review by the Advanced Medical Therapy Committee under the MHLW. Such regenerative medicine therapies are not covered by insurance, but can be combined with other insurance-covered medical treatments after registration with the MHLW Minister's Notification of Advanced Medical Therapy [47, 51].

\section{Conclusions}

In Japan, a new legal framework designed to timely introduce safe and effective regenerative medicines has been implemented recently. Systems to promote research and development and reimbursement schemes of regenerative medicine products are included. It is expected that these changes will accelerate the clinical application and commercialization of innovative regenerative medicine therapy such as those derived from iPS cells.

Acknowledgments The author wishes to thank Dr. Peter Karagiannis for the critical reading of the manuscript. This work was supported in part by Japan Science and Technology Agency Research Center Network for Realization of Regenerative Medicine.

\section{Compliance with Ethics Guidelines}

Conflict of Interest Kentaro Azuma reports grants from the Japan Science and Technology Agency and personal fees from the Ministry of Health, Labour, and Welfare.

Human and Animal Rights and Informed Consent This article does not contain any studies with human or animal subjects performed by any of the authors. 


\section{References}

Papers of particular interest, published recently, have been highlighted as:

- Of importance

1. Takahashi K, Yamanaka S. Induction of pluripotent stem cells from mouse embryonic and adult fibroblast cultures by defined factors. Cell. 2006;126:663-76. doi:10.1016/j.cell.2006.07.024.

2. Government of Japan. The Regenerative Medicine Promotion Act (the act regarding policy package to provide national citizens regenerative medicine timely and safely). 2013 Act No.13. [in Japanese].

3. Government of Japan. The Pharmaceuticals and Medical Devices Act (the act on securing quality, efficacy and safety of pharmaceuticals, medical devices, etc.). 1960 Act No. 145. [in Japanese].

4. Government of Japan. The Act on the Partial Revision of the Pharmaceutical Affairs Law. 2013 Act No.84. [in Japanese]. This act includes regulatory framework to secure quality, efficacy and safety of the regenerative medicine products.

5. Government of Japan. The Act on the Safety of Regenerative Medicine. 2013 Act No.85. [in Japanese]. This act covers regulation to secure safety of the regenerative medicine therapy provided under the responsibility of medical institutions.

6. Cyranoski D. Japan to offer fast-track approval path for stem cell therapies. Nat Med. 2013;19:510. doi:10.1038/nm0513-510.

7. Hara A, Sato D, Sahara Y. New governmental regulatory system for stem cell-based therapies in Japan. Ther Innov Regul Sci. 2014;48: 681-8. doi:10.1177/2168479014526877.

8. Okada K. A new national framework for clinical trials and evaluation of innovative medical care technologies using living cell transplantation in Japan. J Transplant Technol Res. 2014;4:137. doi:10. 4172/2161-0991.1000137.

9. Government of Japan. The Act on the Partial Revision of the Pharmaceutical Affairs Law and the Blood Collection and Donation Service Control Act. 2002 Act No. 96. [in Japanese].

10. Pharmaceuticals and Medical Device Agency (PMDA). Review report of JACE (in English). August 6, 2007. http://www.pmda. go.jp/english/service/pdf/medical_devices/jace_oct2007_e.pdf Accessed 1 Feb 2015.

11. PMDA. Review result report of JACC. June 5, 2012. http://www. info.pmda.go.jp/nmdevices/M201200024/340938000 22400BZX00266000_R100_2.pdf [in Japanese] Accessed 1 Feb 2015.

12. Yano K, Watanabe N, Tsuyuki K, et al. Regulatory approval for autologous human cells and tissue products in the United States, the European Union, and Japan. Regen Ther. 2015;1:45-56. doi:10. 1016/j.reth.2014.10.001.

13. Ministry of Health, Labour and Welfare (MHLW). The list of those deemed as having obtained a license or approval of the regenerative medicine products. 2014 Medical Device and Regenerative Medicine Product Evaluation Division Director's Notice 1105 No.1. [in Japanese].

14. Cyranoski D. Japanese woman is first recipient of next-generation stem cells. Nat New. 2014. doi:10.1038/nature.2014.15915.

15. Cyranoski D. Next-generation stem cells cleared for human trial. Nat New. 2014. doi:10.1038/nature.2014.15897.

16. MHLW. Guidelines for clinical research using human stem cells. 2006 MHLW ministerial notification No.425, 2010 MHLW Ministerial Notification No.380, 2013 MHLW Ministerial Notification No.317. [in Japanese].

17. Government of Japan. The Medical Practitioners' Act. 1948 Act No.201. http://www.japaneselawtranslation.go.jp/law/detail/?ft=
$4 \& \mathrm{re}=01 \& \mathrm{dn}=1 \& \operatorname{ty}[]=\mathrm{A} \& \operatorname{ty}[]=\mathrm{B} \& \operatorname{ty}[]=\mathrm{C} \& \operatorname{ty}[]=\mathrm{Z} \& \mathrm{ia}=03 \& \mathrm{x}=$ $75 \& y=26 \& t a=h 0 \& k y=\& p a g e=3$ Accessed 1 Feb 2015.

18. Government of Japan. The Medical Care Act. 1948 Act No.205. http://www.japaneselawtranslation.go.jp/law/detail/?ft=4\&re= $01 \& \operatorname{dn}=1 \& \operatorname{ty}[]=\mathrm{A} \& \operatorname{ty}[]=\mathrm{B} \& \operatorname{ty}[]=\mathrm{C} \& \operatorname{ty}[]=\mathrm{Z} \& \mathrm{ia}=03 \& \mathrm{x}=75 \& \mathrm{y}=$ $26 \& t a=h 0 \& k y=\& p a g e=6$ Accessed 1 Feb 2015.

19. Yanagi K, Fukuda E, Jotatsu Y, et al. Regulatory frameworks for cell therapy products in Japan. J Artif Organs. 2012;15:325-30. doi: 10.1007/s10047-012-0653-5.

20. Cyranoski D. Korean deaths spark inquiry. Nature. 2010;468:485. doi:10.1038/468485a.

21. Okano T. Recommendation for members of the Japanese society for regenerative medicine. The Japanese society for regenerative medicine. March 1, 2011. http://www.asas.or.jp/jsrm/announcements/ 110303.html [in Japanese] Accessed 1 Feb 2015.

22. Editorials. Unknown territory. Nat. 2013;494:5.

23. Nakauchi H. Statement for deregulation toward realization of regenerative medicine. The Japanese Society for Regenerative Medicine. March 5, 2009. http://www.asas.or.jp/jsrm/ announcements/090305.html [in Japanese] Accessed 1 Feb 2015.

24. Government of Japan. The Pharmaceuticals and Medical Device Agency Act (the Act on the Incorporated Administrative Agency of the Pharmaceuticals and Medical Device Agency). 2002 Act No.192. [in Japanese].

25. MHLW. Regarding establishment of regulatory framework to promote and secure safety of regenerative medicine, report of special committee to promote and secure safety of regenerative medicine, health science council. April 18, 2013. http://www.mhlw.go.jp/stf/ shingi/2r9852000002zggt.html [in Japanese] Accessed 1 Feb 2015

26. Nakamura S, Takayama N, Hirata S, et al. Expandable megakaryocyte cell lines enable clinically applicable generation of platelets from human induced pluripotent stem cells. Cell Stem Cell. 2014;14:535-48. doi:10.1016/j.stem.2014.01.011.

27. The International Conference on Harmonisation of Technical Requirements for Registration of Pharmaceuticals for Human Use (ICH). Guideline for good clinical practice E6(R1). ICH harmonized tripartite guideline. Jun 1996. http://www.ich.org/fileadmin/ Public_Web_Site/ICH_Products/Guidelines/Efficacy/E6/E6_R1_ Guideline.pdf Accessed 1 Feb 2015.

28. English Regulatory Information Task Force of Japan Pharmaceutical Manufacturers Association. Pharmaceutical administration and regulations in Japan. Mar 2011. http://www.nihs. go.jp/mhlw/yakuji/yakuji-e_20110502-02.pdf Accessed 1 Feb 2015.

29. Government of Japan. Cartagena Domestic Act (the act concerning the conservation and sustainable use of biological diversity through regulations on the use of living modified organisms). 2003 Act No.97. [in Japanese].

30. Government of Japan. The act on securing a stable supply of safe blood products. 1956 Act No.160. [in Japanese].

31. Government of Japan. The cabinet ordinance for the enforcement of the Act on the Safety of Regenerative Medicine. 2014 Cabinet Ordinance No.278. [in Japanese].

32. MHLW. The ministerial ordinance for the enforcement of the Act on the Safety of Regenerative Medicine. 2014 MHLW Ministerial Ordinance No.110. [in Japanese].

33. MHLW. The scope of regenerative medicine subject to the Act on Safety of Regenerative Medicine (draft), committee to promote and secure safety of regenerative medicine, health science council. January 29, 2014. http://www.mhlw.go.jp/stf/shingi/0000033201. html [in Japanese] Accessed 1 Feb 2015.

34. Government of Japan. Registration and License Tax Act. 1967 Act No.35. [in Japanese].

35. Government of Japan. Basic policy to promote the R\&D, provision and dissemination of regenerative medicine timely and safely. Cabinet Decision, November 25, 2013. http://www.mhlw.go.jp/ 
file/06-Seisakujouhou-10800000-Iseikyoku/0000066238.pdf [in Japanese] Accessed 1 Feb 2015.

36. Government of Japan. The act on the incorporated administrative agency of Japan Agency for Medical Research and Development. 2014 Act No. 49. [in Japanese].

37. Government of Japan. The Act to Promote Healthcare and Medical Strategy. 2014 Act No.48. [in Japanese].

38. Government of Japan. The act on the arrangement of related acts that accompany the enforcement of acts that revise parts of act on general rules for incorporated administrative agency. 2014 Act No 67. [in Japanese]

39. Government of Japan. Healthcare and medical strategy. Cabinet Decision. July 22, 2014. http://www.kantei.go.jp/jp/singi/ kenkouiryou/suisin/ketteisiryou/dai2/siryou1.pdf [in Japanese] Accessed 1 Feb 2015

40. Government of Japan. Plan for the promotion of medical research and development. Decision by headquarter of promotion of healthcare and medical strategy. July 22, 2014. http://www.kantei. go.jp/jp/singi/kenkouiryou/suisin/ketteisiryou/dai2/siryou2.pdf [in Japanese] Accessed 1 Feb 2015.

41. Government of Japan. The Patent Act. 1959 Act No.121. [in Japanese].

42. Government of Japan. The cabinet ordinance for the enforcement of the Patent Act. 1960 Cabinet Ordinance No.16. [in Japanese].

43. Japan Patent Office. Examination criteria for patent term extensions. November 19, 2014. https://www.jpo.go.jp/tetuzuki_e/t_ tokkyo_e/Guidelines/6.pdf Accessed 1 Feb 2015.
44. Ministry of Economy, Trade and industry. Report from working group on the patent term extension of regenerative medicine products. Industrial Structure Council. Feb 2014. http://www.jpo.go.jp/ shiryou/toushin/toushintou/saiseii-wg_houkoku.htm [in Japanese] Accessed 1 Feb 2015

45. Government of Japan. Health Insurance Act. 1922 Act No.70. [in Japanese].

46. MHLW. Medical material price list. 2010 MHLW ministerial notification no. 61, 2014 MHLW Ministerial Notification No. 62. [in Japanese].

47. MHLW. Regarding regenerative medicine products (draft). General Committee, Central Social Insurance Medical Council. November 5, 2014. http://www.mhlw.go.jp/stf/shingi2/0000063842.html [in Japanese] Accessed 1 Feb 2015.

48. MHLW. Drug price list. 2010 MHLW ministerial notification No. 60, 2014 MHLW Ministerial Notification No. 61. [in Japanese].

49. MHLW. Evaluation treatment and selective treatment prescribed by the minister of health, labour and welfare. 2008 MHLW Ministerial Notification No. 495, 2014 MHLW Ministerial Notification No. 422. [in Japanese].

50. MHLW. Calculation of the amount of expenses incurred in providing the benefits for medical treatment combined with treatment outside insurance coverage. 2008 MHLW Ministerial Notification No. 496, 2014 MHLW Ministerial Notification No. 423. [in Japanese].

51. MHLW. Advanced medical therapies and institutional standards prescribed by the minister of health, labour and welfare. 2010 MHLW Ministerial Notification No. 129. [in Japanese]. 